
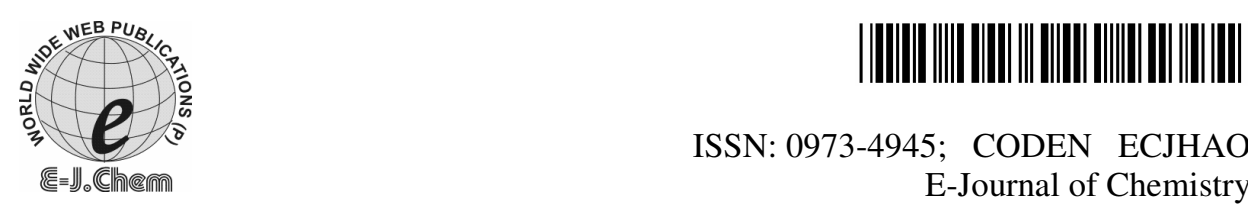

ISSN: 0973-4945; CODEN ECJHAO

http://www.e-journals.net

E-Journal of Chemistry

2009, 6(1), 99-105

\title{
Bioinorganic Relevance of Some Cobalt(II) Complexes with Thiophene-2-glyoxal Derived Schiff Bases
}

\author{
PRASHANT SINGH, SHANU DAS and RAJESH DHAKAREY
}

Department of Chemistry, Institute of Basic Science, Dr. B.R.A. University, Agra- 282005, Uttar Pradesh, India.

prashantsingh_11@rediffmail.com

Received 28 February 2008; Revised17 July 2008; Accepted 10 September 2008

\begin{abstract}
Complexes of Co(II) with two new Schiff bases TEAB [2-hydroxy-4\{[2-oxo-2-(thiophen-2-yl)ethylidene]amino $\}$ benzoic acid] and TEPC [ $N$-[2-oxo2-(thiophen-2-yl)ethylidene]pyridine-3-carboxamide] have been synthesized and characterized with the help of elemental analysis, magnetic, mass, ${ }^{1} \mathrm{H}-\mathrm{NMR}$, ${ }^{13} \mathrm{C}-\mathrm{NMR}$, IR and electronic spectral data. IR spectra manifest the coordination of the ligand to the metal ion through the carbonyl oxygen, azomethine nitrogen and thienyl sulphur atoms. With the help of electronic spectral data various ligand field parameters were also calculated. All these studies reveal the distorted octahedral $\mathrm{Co}$ (II) complexes. Synthesized compounds have also been screened against some micro organisms viz, Escherichia coli, Proteus vulgaris, Aspergillus niger and Aspergillus flavus with the help of 'filter paper disc' technique. It has been observed that the antimicrobial activities of metal complexes are higher than that of the free ligand.
\end{abstract}

Keywords: Schiff base, Magnetic, Electronic, Mass, NMR and Infrared studies, Octahedral Co(II) complexes, Antimicrobial studies.

\section{Introduction}

In the field of coordination complexes, Schiff base metal complexes ${ }^{1}$ have a curious history. Considerable interest attached with the chemistry of Schiff bases ${ }^{2}$ derived from heterocyclic aldehydes, glyoxals and primary amines. Various heterocyclic Schiff bases having oxygen, nitrogen and sulphur donor atoms, have been reported by several scientists ${ }^{3}$. In recent years, applications of Schiff bases and their metal complexes in pharmacological ${ }^{4}$ and nonpharamcological ${ }^{5}$ fields have been receiving increased attention.

In the course of present investigation, complex formation of TEAB [2-hydroxy-4-\{[2oxo-2-(thiophen-2-yl)ethylidene]amino benzoic acid] and TEPC [ $N$-[2-oxo-2-(thiophen-2yl)ethylidene] pyridine-3-carboxamide] Schiff bases with $\mathrm{Co}(\mathrm{II})$ ion have been attempted. 
Magnetic and electronic spectral data of these Co(II) complexes have been discussed on the basis of ligand field theory and the reacting sites in the ligands have been suggested on the basis of IR spectra. Mass and NMR spectral studies have been also discussed for the Schiff bases. In view of biological importance of these ligands and complexes, antibacterial and antifungal activities have also been screened.

\section{Experimental}

All the chemicals used were of AR grade and used without further purification. 2-acetyl thiophene ${ }^{6}$ and 2 -thienyl glyoxal ${ }^{7}$ were prepared by slightly modified techniques of the literature methods.

\section{Synthesis of TEAB}

A mixture of 2-thienyl glyoxal (14 mL, $10 \mathrm{~m} \mathrm{~mol})$ dissolved in $40 \mathrm{~mL}$ acetone and $p$-amino salicylic acid (15.3 g, $10 \mathrm{~m} \mathrm{~mol})$ dissolved in $20 \mathrm{~mL}$ ethanol was refluxed on water bath for $6 \mathrm{~h}$ under stirring. On cooling to room temperature, dark purple brown crystals were obtained. The crystals were filtered and washed with ethanol, recrystallized from acetone and dried at ambient temperature and its purity was confirmed by TLC technique.

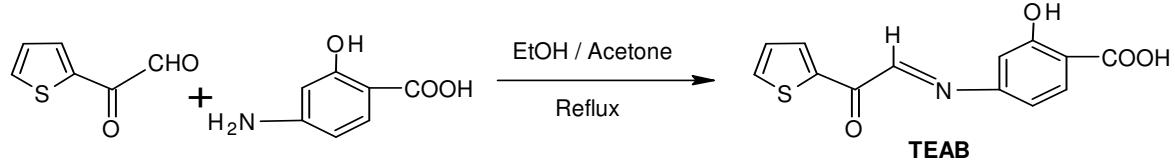

Figure 1. Synthesis of TEAB.

\section{Synthesis of TEPC}

A mixture of 2-thienyl glyoxal $(14 \mathrm{~mL}, 10 \mathrm{~m} \mathrm{~mol})$ dissolved in $40 \mathrm{~mL}$ acetone and nicotinamide (12 g, $10 \mathrm{~m} \mathrm{~mol})$ dissolved in $20 \mathrm{~mL}$ ethanol was refluxed on water bath for $6 \mathrm{~h}$ under stirring. On cooling to room temperature, chocolate brown crystals were obtained. The crystals were filtered and washed with ethanol, recrystallized from acetone and dried at ambient temperature and its purity was confirmed by TLC technique.

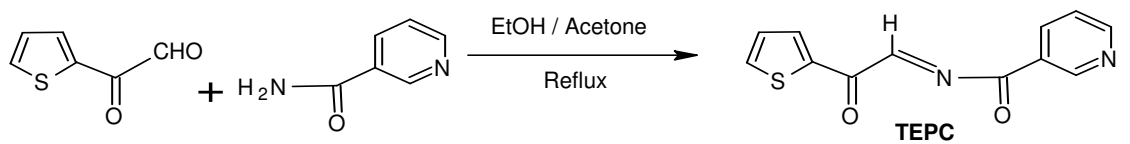

Figure 2. Synthesis of TEPC.

\section{Synthesis of complexes}

A solution of Co(II) salt (chloride / nitrate $10 \mathrm{~m} \mathrm{~mol}$ ) in $20 \mathrm{~mL}$ ethanol was directly mixed to the solution of the ligand TEAB / TEPC in the same solvent. The molar ratio of metal: ligand was 1:2 for both TEAB and TEPC Schiff bases. Reflux the above mixture for 3-4 h. On cooling, filter the product and the material was dried in air to get the crystals of metal chelates. The yield varied from $40-60 \%$.

\section{Physical measurements}

Percentage of $\mathrm{C}, \mathrm{N}$ and $\mathrm{H}$ were determined micro analytically at RSIC, Punjab Univ. Chandigarh and the percentage of $\mathrm{Co}$ (II) in the complexes was determined by the standard method using pyridine and ammonium thiocyanate as precipitants. Melting points of the synthesized compounds were determined in open glass capillaries using melting point apparatus. Magnetic susceptibility measurements were determined at room temperature on 'EG\&G model-155' by VSM (vibrating sample magnetometer) method at RSIC, IIT- Madras. 
The NMR spectra were recorded on Bruker-300 Ultrashield-300 MHz NMR spectrometer. The mass spectra were recorded at Torrent Pharmaceuticals Ltd., Ahmedabad. Electronic spectra of complexes were carried out on 'Elico SL-171' spectrometer at $25^{\circ} \mathrm{C}$ using ethanol/acetone as solvent at Department of Chemistry, R.B.S. College, Agra. IR spectra were recorded using $\mathrm{KBr}$ pellets on 'Perkin Elmer-137 and 577' spectrometer in the region $\sim 4000-200 \mathrm{~cm}^{-1}$ at Alembic Ltd. Vadodara and RSIC, Punjab Univ., Chandigarh .

\section{Results and Discussion}

\section{Mass spectral studies}

On the basis of the "bar graph" presentation of the Schiff bases, we can observed that the peaks at $\mathrm{m} / z 154$ and $\mathrm{m} / z, 126$ are the parent ion peaks of the Schiff bases TEAB and TEPC respectively and the peak at $\mathrm{m} / \mathrm{z} 274$ and $\mathrm{m} / \mathrm{z} 244$ is corresponding to the molecular weight $\left(\mathrm{M}^{+}\right)$of the TEAB and TEPC respectively.

In the case of TEAB other peaks at $\mathrm{m} / \mathrm{z} 230,257,137$ and 190 supports the fragmentation of carboxylic group, hydroxyl group, salicylic acid and thiophene ring respectively. Peaks at $\mathrm{m} / \mathrm{z} 150$ and $\mathrm{m} / \mathrm{z} 124$ are due to the fragmentation at the azomethine linkage.

In the case of TEPC other peaks at $\mathrm{m} / \mathrm{z} 166$ and $\mathrm{m} / \mathrm{z} 160$ supports the loss of pyridine ring and thiophene ring respectively. Peaks at $\mathrm{m} / \mathrm{z} 121$ and $\mathrm{m} / \mathrm{z} 124$ are due to the fragmentation at the azomethine linkage. Therefore, the observed fragmented ion peaks for both the Schiff bases are also in confirmation with their structures.

\section{NMR spectral studies}

\section{${ }^{1} H N M R$}

${ }^{1} \mathrm{H}$ NMR spectrum of Schiff bases TEAB \& TEPC were recorded in $\mathrm{CDCl}_{3}$. In the spectra of TEAB, a sharp singlet at $\delta 8.21$ assigned as azomethine proton and a broad singlet found due to hydroxylic proton and carboxylic $\mathrm{OH}$ having in the chemical shift range of $\delta 10.31-\delta$ 11.33. Peaks due to thienyl protons present at position $3,4 \& 5$ found at $(\mathrm{s}, \delta 8.00),(\mathrm{m}, \delta$ $6.92)$ and $(\mathrm{t}, \delta 7.37)$ respectively. Peaks due to protons present in benzene ring at position 3,5 $\& 6$ found at $(\mathrm{d}, \delta 6.85),(\mathrm{d}, \delta 6.77)$ and $(\mathrm{d}, \delta 7.90)$ respectively.

In the spectra of TEPC, a sharp singlet peak at $\delta 8.43$ is present due to azomethine proton. Peaks due to thienyl protons present at position $3,4 \& 5$ found at (s, $\delta 8.04),(\mathrm{m}, \delta$ $7.50)$ and $(\mathrm{t}, \delta 7.05)$ respectively. Peaks due to protons present in pyridine ring at position 2 , $4,5 \& 6$ found at $(\mathrm{d}, \delta 9.25),(\mathrm{m}, \delta 8.30),(\mathrm{m}, \delta 7.58)$ and $(\mathrm{m}, \delta 8.58)$ respectively.

\section{${ }^{13}$ C NMR}

${ }^{13} \mathrm{C}$ NMR spectrum of both the Schiff bases was also recorded in $\mathrm{CDCl}_{3}$. In the spectra of TEAB, peaks due to azomethine carbon, carbonyl carbon and carboxylic carbon found at $\delta$ $160.11, \delta 186.52$ and $\delta 172.44$ respectively. Chemical shift due to the carbon atoms present in the thiophene ring, at position $2,3,4 \& 5$ has been found at $\delta 145.59, \delta 133.78, \delta 124.97$ and $\delta$ 128.03 respectively and Chemical shifts due to the benzene ring, for the position 1 to 6 has been found at $\delta 100.26, \delta 164.15, \delta 108.37, \delta 150.86, \delta 116.50$ and $\delta 130.72$ respectively.

In the spectra of TEPC, peaks due to azomethine carbon found at $\delta 160.33$. Chemical shift due to carbonyl carbon attached to thiophene ring found at $\delta 184.14$ and carbonyl carbon attached to pyridine ring found at $\delta 173.59$. Chemical shift due to the carbon atoms present in the thiophene ring, at position $2,3,4 \& 5$ has been found at $\delta 150.48, \delta 133.12, \delta 123.46$ and $\delta 129.22$ 
respectively. Chemical shifts found at $\delta 152.00, \delta 135.26, \delta 138.70, \delta 125.79$ and $\delta 156.50$ are due to the $2,3,4,5 \& 6$ carbon position of the pyridine ring respectively. By the help of above ${ }^{1} \mathrm{H}$ and ${ }^{13} \mathrm{C}$ NMR spectra features, we can propose the structures of both the Schiff bases.

\section{Magnetic susceptibility measurements}

The effective magnetic moment values of all the Co(II)complexes lie in the range of 4.5-5.2 $\mathrm{BM}$, which suggested a distorted octahedral geometry ${ }^{8}$ (Table 1). These values are much higher than the spin only value of $3.87 \mathrm{BM}$. These $\mu_{\text {eff }}$ values in all the complexes may arise due to electron pairing in the formation of strong covalent bond involving the use of $3 \mathrm{~d}$ electron of $\mathrm{Co}(\mathrm{II})$ ion or spin-spin interaction.

Table 1. Analytical, magnetic and physical properties of ligands and their $\mathrm{Co}(\mathrm{II})$ complexes.

\begin{tabular}{|c|c|c|c|c|c|c|c|c|c|c|}
\hline \multirow{2}{*}{ S.No } & \multirow{2}{*}{ Compounds } & \multirow{2}{*}{$\begin{array}{c}\text { m.p. } \\
{ }^{\circ} \mathrm{C}\end{array}$} & \multirow{2}{*}{ Color } & \multicolumn{6}{|c|}{ Elemental analysis ( $\%$ found / Calculated) } & \multirow{2}{*}{$\begin{array}{c}\mu_{\text {eff. }} \\
\text { (B.M.) }\end{array}$} \\
\hline & & & & $\mathrm{C}$ & $\mathrm{H}$ & $\mathrm{N}$ & $\mathrm{S}$ & $\mathrm{Cl}$ & $\mathrm{M}$ & \\
\hline \multirow{2}{*}{\multicolumn{2}{|c|}{ 1. TEAB }} & \multirow{2}{*}{$98-100$} & & & $3.26 /$ & $5.36 /$ & $11.02 /$ & & & \\
\hline & & & & 56.72 & 3.29 & 5.08 & 11.64 & & & \\
\hline 2. & $\mathrm{Co}(\mathrm{TEAB})_{2} \mathrm{Cl}_{2}$ & $110-115$ & $\begin{array}{l}\text { Dark- } \\
\text { brown }\end{array}$ & $\begin{array}{c}45.33 / \\
45.89\end{array}$ & $\begin{array}{l}2.50 / \\
2.66\end{array}$ & $\begin{array}{c}4.02 / \\
4.22\end{array}$ & $\begin{array}{l}9.92 / \\
9.32\end{array}$ & $\begin{array}{c}10.83 / \\
10.42\end{array}$ & $8.5 / 8.6$ & 4.7 \\
\hline 3. & $\mathrm{Co}(\mathrm{TEAB})_{2}\left(\mathrm{NO}_{3}\right)_{2}$ & $85-90$ & $\begin{array}{l}\text { Reddish } \\
\text { brown }\end{array}$ & $\begin{array}{r}42.01 / \\
42.57\end{array}$ & $\begin{array}{l}2.55 / \\
2.47\end{array}$ & $\begin{array}{l}7.63 / \\
7.29\end{array}$ & $\begin{array}{l}8.30 / \\
8.74\end{array}$ & & $\begin{array}{l}7.97 / \\
8.03\end{array}$ & 5.00 \\
\hline \multicolumn{2}{|c|}{ 4. TEPC } & $95-98$ & $\begin{array}{r}\text { Choc } \\
\text { bro }\end{array}$ & $\begin{array}{r}58.8 / \\
59.9\end{array}$ & $\begin{array}{l}3.34 / \\
3.30\end{array}$ & $\begin{array}{c}12.2 / \\
11.4\end{array}$ & $\begin{array}{c}13.47 / \\
13.12\end{array}$ & & & . \\
\hline 5. & $\mathrm{Co}(\mathrm{TEPC})_{2} \mathrm{Cl}_{2}$ & $112-124$ & $\begin{array}{l}\text { Pale- } \\
\text { brown }\end{array}$ & $\begin{array}{l}38.12 / \\
38.52\end{array}$ & $\begin{array}{l}2.26 / \\
2.15\end{array}$ & $\begin{array}{l}7.02 / \\
7.48\end{array}$ & $\begin{array}{l}8.93 / \\
8.57\end{array}$ & $\begin{array}{c}18.17 / \\
18.95\end{array}$ & $\begin{array}{c}16.01 / \\
15.75\end{array}$ & 4.5 \\
\hline 6. & $\mathrm{Co}(\mathrm{TEPC})_{2}\left(\mathrm{NO}_{3}\right)_{2}$ & $80-85$ & $\begin{array}{l}\text { Dark- } \\
\text { brown }\end{array}$ & $\begin{array}{l}33.29 / \\
33.73 \\
\end{array}$ & $\begin{array}{c}2.01 / \\
1.88\end{array}$ & $\begin{array}{l}13.6 / \\
13.11 \\
\end{array}$ & $\begin{array}{l}7.60 / \\
7.40 \\
\end{array}$ & - & $\begin{array}{r}13.3 / \\
13.79 \\
\end{array}$ & 5.2 \\
\hline
\end{tabular}

\section{Electronic spectral studies}

The distorted octahedral geometry of the complexes was also supported by electronic spectra ${ }^{9}$ of these complexes. The electronic spectra of the Co(II) complexes gave three bands. Konig's method $^{10}$ was used to ascertain the correct positions of the bands. In the complex $\left[\mathrm{Co}(\mathrm{TEAB})_{2} \mathrm{Cl}_{2}\right]$ (a) , the assignments of the spectral bands are as follows: ${ }^{4} \mathrm{~T}_{2 \mathrm{~g}}(\mathrm{~F}) \leftarrow{ }^{4} \mathrm{~T}_{1 \mathrm{~g}}\left(v_{1}\right)$ $\approx 8225 \mathrm{~cm}^{-1},{ }^{4} \mathrm{~A}_{2 \mathrm{~g}} \leftarrow{ }^{4} \mathrm{~T}_{1 \mathrm{~g}}(\mathrm{~F})\left(v_{2}\right) \approx 17551 \mathrm{~cm}^{-1}$, and ${ }^{4} \mathrm{~T}_{1 \mathrm{~g}}(\mathrm{P}) \leftarrow{ }^{4} \mathrm{~T}_{1 \mathrm{~g}}(\mathrm{~F})\left(v_{3}\right) \approx 20980 \mathrm{~cm}^{-1}$. The ligand field parameters $v_{3} / v_{1}, v_{3} / v_{2}$, Dq/B, B and $\beta$ values have been found to be $2.55,1.99,0.67,931$ and 0.95 respectively, which agree with the values of distorted octahedral $\mathrm{Co}$ (II) complexes.

The spectrum of $\left[\mathrm{Co}(\mathrm{TEAB})_{2}\left(\mathrm{NO}_{3}\right)_{2}\right](\mathrm{b})$, showed three absorption bands around $v_{1} \sim$ $10120, v_{2} \sim 19600$ and $v_{3} \sim 22090 \mathrm{~cm}^{-1}$, which may be attributed to the three spin-allowed transitions. Same as mentioned above and the values of parameters $v_{3} / v_{1}, v_{3} / v_{2}, \mathrm{Dq} / \mathrm{B}, \mathrm{B}$ and $\beta$ are 2.18, 1.12, 1.10, 946 and 0.97 and 0.97 respectively, expected for a distorted octahedral ${ }^{12}$ structure. In the electronic spectrum of $\left[\mathrm{Co}(\mathrm{TEPC})_{2} \mathrm{Cl}_{2}\right](\mathrm{c})$, the three absorption bands are at $v_{1}=8285, v_{2}=17680$ and $v_{3}=20075 \mathrm{~cm}^{-1}$ and for complex $\left[\mathrm{Co}(\mathrm{TEPC})_{2}\left(\mathrm{NO}_{3}\right)_{3}\right]$ (d), these values are at 11655,20080 and $22970 \mathrm{~cm}^{-1}$ respectively. The ligand field parameters for these complexes are also in the range (Table 2), suggesting distorted octahedral geometry of these $\mathrm{Co}(\mathrm{II})$ complexes.

Various other crystal and ligand field parameters ${ }^{13}$ for all the Co(II) complexes have been also calculated. The values of these parameters are also in confirmation with distorted octahedral complexes (Table 2). 
Table 2. Electronic spectral data and compound values of some ligand field parameters for Co (II) complexes

\begin{tabular}{lllll}
\hline & \multicolumn{4}{c}{ Complexes } \\
\cline { 2 - 5 } Parameters & $\mathrm{Co}(\mathrm{TEAB})_{2} \mathrm{Cl}_{2}$ & $\mathrm{Co}(\mathrm{TEAB})_{2}\left(\mathrm{NO}_{3}\right)_{2}$ & $\mathrm{Co}(\mathrm{TEPC})_{2} \mathrm{Cl}_{2}$ & $\mathrm{Co}(\mathrm{TEPC})_{2}\left(\mathrm{NO}_{3}\right)_{2}$ \\
\hline$v_{1}$ & 8225 & 10120 & 8285 & 11655 \\
$v_{2}$ & 17551 & 19600 & 17680 & 20080 \\
$v_{3}$ & 20980 & 22090 & 20075 & 22970 \\
$\mathrm{~B}$ & 931 & 946 & 863 & 1044 \\
$\mathrm{C}$ & 4189.5 & 4257 & 38863.5 & 4698 \\
$\mathrm{~F}^{2}$ & 1529.5 & 1554 & 1417.7 & 1715 \\
$\mathrm{~F}^{4}$ & 119.7 & 121.6 & 110.9 & 134.2 \\
$10 \mathrm{Dq}$ & 6259 & 10433 & 9414 & 10950 \\
$\mathrm{Dq} / \mathrm{B}$ & 0.67 & 1.10 & 1.09 & 1.04 \\
$\mathrm{f}$ & 695.4 & 1159.2 & 1046 & 1216.6 \\
$\mathrm{~h}$ & 0.208 & 0.208 & 0.916 & -0.29 \\
$\beta$ & 0.95 & 0.97 & 0.88 & 1.07 \\
$\beta \%$ & 5 & 3.2 & 12 & -7 \\
$v_{3} / v_{1}$ & 2.55 & 2.18 & 2.42 & 1.97 \\
$v_{3} / v_{2}$ & 1.19 & 1.12 & 1.13 & 1.14 \\
$\pi$ & 14960.2 & 16963.8 & 15679.3 & 18769.6 \\
$\Pi$ & 1973.7 & 2005.5 & 1829.5 & 2213.2 \\
$\Pi / \mathrm{B}$ & 2.12 & 2.12 & 2.12 & 2.12 \\
\hline
\end{tabular}

[Here $v_{1}, v_{2} \& v_{3}=$ Observed spin allowed transition, $B \& C=$ Racah parameters, $F^{2} \& F^{4}=$ SlatorCondon parameters, $10 D q=$ Crystal field parameter from numerical fitting, $f \& h=$ Crystal field and Nephaleuxetic parameters for the ligands used in the complexes, $\beta \& \beta \%=$ Nephaleuxetic ratio and (\%) covalence character, $\pi=$ Mean pairing energy, $\Pi=$ Exact spin pairing energy]

\section{Infrared spectral studies}

In order study the binding mode of the Schiff bases to metal in the complexes, IR spectra ${ }^{14}$ of the free ligands are compared to metal complexes. In the IR spectra of TEAB, three sharp bands found at $\sim 1626, \sim 1289$ and $\sim 1982 \mathrm{~cm}^{-1}$ are due to $v \mathrm{C}=\mathrm{N}, v \mathrm{C}-\mathrm{S}-\mathrm{C}$ and $\nu \mathrm{C}=\mathrm{O}$ bending vibrations respectively. In both the metal complexes of this Schiff base viz. (a) and (b), $v \mathrm{C}=\mathrm{N}$ band shifts to $\sim 1611$ and $\sim 1612 \mathrm{~cm}^{-1}$ respectively, confirms the coordination through azomethine nitrogen ${ }^{15}$. The $v \mathrm{C}-\mathrm{S}-\mathrm{C}$ bands at $\sim 1275$ and $\sim 1277 \mathrm{~cm}^{-1}$ respectively indicates the coordination of thienyl sulphur and $\mathrm{vC}=\mathrm{O}$ bands at $\sim 1701$ and $\sim 1708 \mathrm{~cm}^{-1}$ respectively confirms the involvement of carbonyl oxygen in coordination ${ }^{16}$. The values and the position of the $\mathrm{vOH}$ band are almost retained $+3 \mathrm{~cm}^{-1}$ in these complexes indicates that phenolic oxygen atom do not take part in coordination ${ }^{17}$.

In the IR spectra of TEPC, $v \mathrm{C}=\mathrm{N}, v \mathrm{C}-\mathrm{S}-\mathrm{C}, \mathrm{vC}=\mathrm{O}$ and $\nu \mathrm{C}-\mathrm{N}-\mathrm{C}$ stretching vibrations are at the expected values of $\sim 1618, \sim 1272, \sim 1681$ and $\sim 1690 \mathrm{~cm}^{-1}$ respectively. In the complexes (c) and (d), the ligand band of $\vee \mathrm{C}=\mathrm{N}$ shifted to $\sim 1603$ and $\sim 1610 \mathrm{~cm}^{-1}$ respectively, indicating the coordination of azomethine nitrogen. The $\nu \mathrm{C}$-S-C vibrations of these complexes are at $\sim 1275$ and $\sim 1273 \mathrm{~cm}^{-1}$ respectively, indicates the non involvement of thienyl sulphur with metal. Appearance of the broad peaks at $\sim 1672$ and $\sim 1688 \mathrm{~cm}^{-1}$ respectively, which are due to shifting in $\mathrm{v}=\mathrm{O}$ bands, also indicates the coordination through carbonyl oxygen. The position and other characteristics of the band $\mathrm{vC}-\mathrm{N}-\mathrm{C}$ are retained $\pm 1 \mathrm{~cm}^{-1}$ in both the above complexes ${ }^{18}$. This indicates that the pyridine nitrogen do not take part in coordination. 
In the complexes additional bands are also appear in the region $\sim 287-294 \mathrm{~cm}^{-1}$ and $\sim 1120-1157 \mathrm{~cm}^{-1}$. These vibrations have been ascribed to $v \mathrm{M}-\mathrm{Cl}$ and $v_{2}$ band of $\mathrm{NO}_{3}{ }^{-}$group respectively indicating coordination. All the above coordination sites are further confirmed by the $v \mathrm{M}-\mathrm{O}, v \mathrm{M}-\mathrm{N}$ and $v \mathrm{M}-\mathrm{S}$ stretching bands at the expected values $\sim 520-545$ and $~ 441$ $445 \mathrm{~cm}^{-1}$ and $\sim 331-340 \mathrm{~cm}^{-1}$ respectively ${ }^{19}$ in all the complexes as we have discussed here.

\section{Microbiocidal assay}

Synthesized Schiff bases and their corresponding metal complexes were tested for the growth inhibitory activity against phytopathogenic bacteria viz. Escherichia coli and Proteus vulgaris, and fungi viz. Aspergillus niger and Aspergillus flavus using 'Filter paper disc' method $^{20}$ at 250 , 500 and $1000 \mathrm{ppm}$ level in acetone/ethanol. For screening antibacterial activity 'Nutrient Agar' and for antifungal activity 'Potato Dextrose Agar' ${ }^{21}$ was used as a growth medium. Sterilized filter paper discs of $5 \mathrm{~mm}$ diameter were soaked in the solutions of different concentrations of synthesized compounds and introduced on sterilized culture media. The plates were incubated for 24-30 $\mathrm{h}$ at $35 \pm 2{ }^{\circ} \mathrm{C}$ for bacteria and $72-96 \mathrm{~h}$ at $28{ }^{\circ} \mathrm{C}$ for fungi. The zones of inhibition based upon zone size around the discs were measured. The measured zone of inhibition against the growth of various microorganisms is listed in Table 3. It is clear from the microbiocidal screening data that the metal complexes are more toxic in comparison to their parent ligand itself. Hence complexation increases the antimicrobial activity ${ }^{22}$ such increased activity of the metal complexes can also be explained on the basis of 'Chelation theory' ${ }^{23}$.

Table 3. Antimicrobial data of synthesized compounds

\begin{tabular}{|c|c|c|c|c|c|c|}
\hline \multirow{2}{*}{ S.No } & \multirow{2}{*}{ Compounds } & \multirow{2}{*}{ Conc. ppm } & \multicolumn{4}{|c|}{ Inhibition Zone, in mm } \\
\hline & & & E. coli & P. vulgaris & A. niger & A. flavus \\
\hline \multirow{3}{*}{1.} & \multirow{3}{*}{ TEAB } & 1000 & & 6 & \multirow{3}{*}{$*$} & 10 \\
\hline & & 500 & \multirow{2}{*}{$*$} & 7 & & 9 \\
\hline & & 250 & & 8 & & 8 \\
\hline \multirow{3}{*}{2.} & \multirow{3}{*}{$\mathrm{Co}(\mathrm{TEAB})_{2} \mathrm{Cl}_{2}$} & 1000 & \multirow{4}{*}{$*$} & 8 & \multirow{3}{*}{ * } & 9 \\
\hline & & 500 & & 7 & & 10 \\
\hline & & 250 & & 9 & & 12 \\
\hline \multirow{3}{*}{3.} & \multirow{3}{*}{$\mathrm{Co}(\mathrm{TEAB})_{2}\left(\mathrm{NO}_{3}\right)_{2}$} & 1000 & & 7 & & 12 \\
\hline & & 500 & \multirow[t]{2}{*}{ * } & 9 & \multirow{2}{*}{$*$} & 10 \\
\hline & & 250 & & 11 & & 8 \\
\hline \multirow{3}{*}{4.} & \multirow{3}{*}{ TEPC } & 1000 & 6 & & 8 & \multirow{4}{*}{ * } \\
\hline & & 500 & - & $*$ & 6 & \\
\hline & & 250 & - & & 8 & \\
\hline \multirow{3}{*}{5.} & \multirow{3}{*}{$\mathrm{Co}(\mathrm{TEPC})_{2} \mathrm{Cl}_{2}$} & 1000 & 6 & & 9 & \\
\hline & & 500 & 6 & * & 6 & \multirow[t]{3}{*}{$*$} \\
\hline & & 250 & - & & 8 & \\
\hline \multirow{3}{*}{6.} & \multirow{3}{*}{$\mathrm{Co}(\mathrm{TEPC})_{2}\left(\mathrm{NO}_{3}\right)_{2}$} & 1000 & 8 & & 10 & \\
\hline & & 500 & 8 & $*$ & 6 & \multirow[t]{2}{*}{$*$} \\
\hline & & 250 & 7 & . & 8 & \\
\hline
\end{tabular}

\section{Conclusion}

Note : ('-' = not measurable, ${ }^{*}=$ not tested $)$

All the spectral studies suggest that the Schiff bases are tridentate in nature having $\mathrm{O}, \mathrm{N}$ and $\mathrm{S}$ donor atoms. The complexes having six coordinate system with octahedral geometry. All the compounds are bioactive showing good antimicrobial property. The proposed structures of the complexes are 


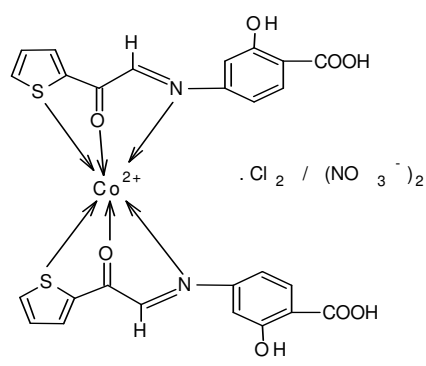

Figure 3. Structure of Complex. $\mathrm{Co}(\mathrm{TEAB})_{2} \mathrm{Cl}_{2} / \mathrm{Co}(\mathrm{TEAB})_{2}\left(\mathrm{NO}_{3}\right)_{2}$

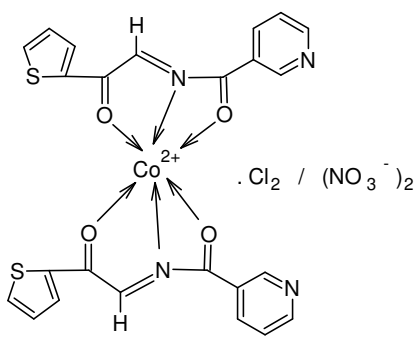

Figure 4. Structure of Complex. $\mathrm{Co}(\mathrm{TEPC})_{2} \mathrm{Cl}_{2} / \mathrm{Co}(\mathrm{TEPC})_{2}\left(\mathrm{NO}_{3}\right)_{2}$

\section{References}

1. Yamada S, Coord Chem Rev., 1999, 537, 190-192.

2. Angellei R J, Coord Chem Rev., 1990, 61, 105.

3. Campbell M J M, J Inorg Nucl Chem., 1974, 55, 36; Dawas H M and Waters T M, Inorg Chim Acta., 1987, 29, 66; Nuria A I, Francisco H U, Miguel N M C, Jose M M M and Maria J R E, J Inorg Biochem, 2008, 102(4), 647.

4. Chohan Z H and Kausar S, Met Based Drugs, 2000, 7(1), 17; Sridhar S K and Ramesh A, Indian J Chem., 2002, 44B(3), 668; Ismail K Z, Trans Met Chem., 2000, 25(5), 522.

5. Declreq B and Verpoort F, J Mol Catalysis, 2002, 180(1-2), 67; Niyazov N A and Timofev V P, Chem Abstr., 2002, 137, 21007v.

6. Vogel A I, Text Book of Practical Organic Chemistry, Longman, London, 1987, 777.

7. Kippnis F and Ornfelt J, J Am Chem Soc., 1946, 68, 273.

8. Dhakarey R and Saxena G, J Chin Chem Soc., 1985, 32, 35; Kumar V and Dhakarey R, J Indian Council Chem., 2003, 20(1), 46.

9. Lever A B P, Inorganic Electronic Spectroscopy, Elsevier, Amsterdam, 1968; Yamada S, Coord Chem Rev, 1967, 2, 83.

10. Konig E, Structure and Bonding, 1975, 9, 175.

11. Figgis B N, Introduction to Ligand Field Theory, Wiley Eastern, New Delhi, 1978.

12. Sallam S A, Oberoi A S and Lentz A, Trans Met Chem., 2002, 24(4), 447.

13. Dutta R L and Syamal A, Elements of Magnetochemistry, East West Press, New Delhi, 1993.

14. Nakamoto K, Infrared and Raman Spectra of Inorganic and Coordination Compounds, John Wiley \& Sons, New York, 1997.

15. Satpathy M and Pradhan B, J Indian Chem Soc., 1998, 75, 518.

16. Reddy K and Lingappa V, Indian J Chem., 1994, 33A, 959.

17. Basseler G C and Silverstein R M, Spectrometric Identification of Organic Compounds, Wiley Interscience, New York, 1992.

18. Dayer J R, Applications of Absorption Spectroscopy of Organic Compounds, Prentice Hall, New Delhi, 1974.

19. Parihari R K, Patel R K and Patel R N, J Indian Chem Soc., 1999, 76, 258.

20. Baur A W, Kirby W M, Sherris J C and Turk M, Am J Clin Path., 1966, 45, 493.

21. Alexopoulos C J and E S Beneke, Laboratory Manual for Introductory Mycology, Burgess Pub. Co, Minneapolis, 1962.

22. Anjaneyula Y and Rao P P, Synth React Inorg Met Org Chem., 1986, 26, 257.

23. Thimmaiah K N, Lloyd W D and Chandrappa G T, Inorg Chim Acta, 1985, 81, 106. 


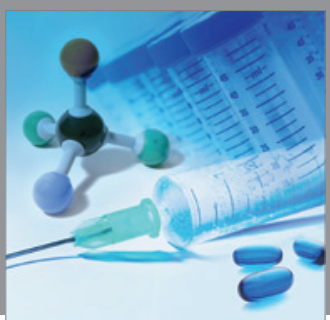

International Journal of

Medicinal Chemistry

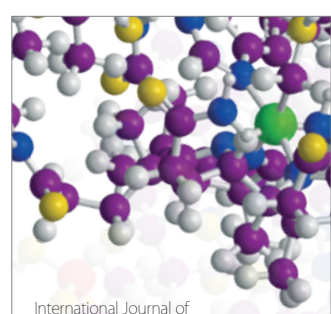

Carbohydrate Chemistry

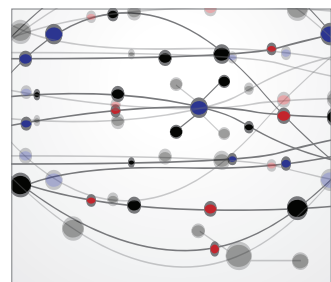

The Scientific World Journal
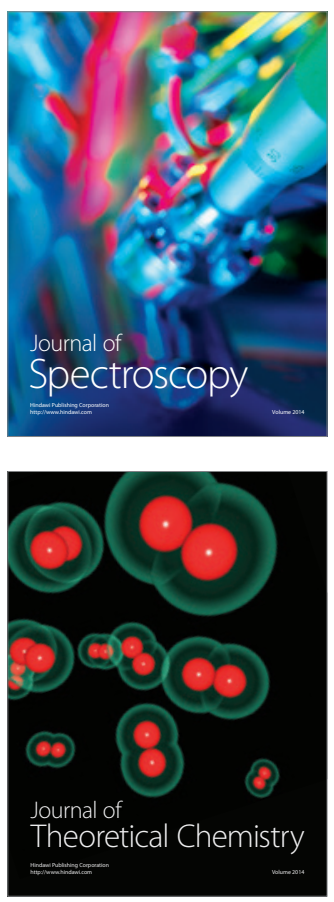
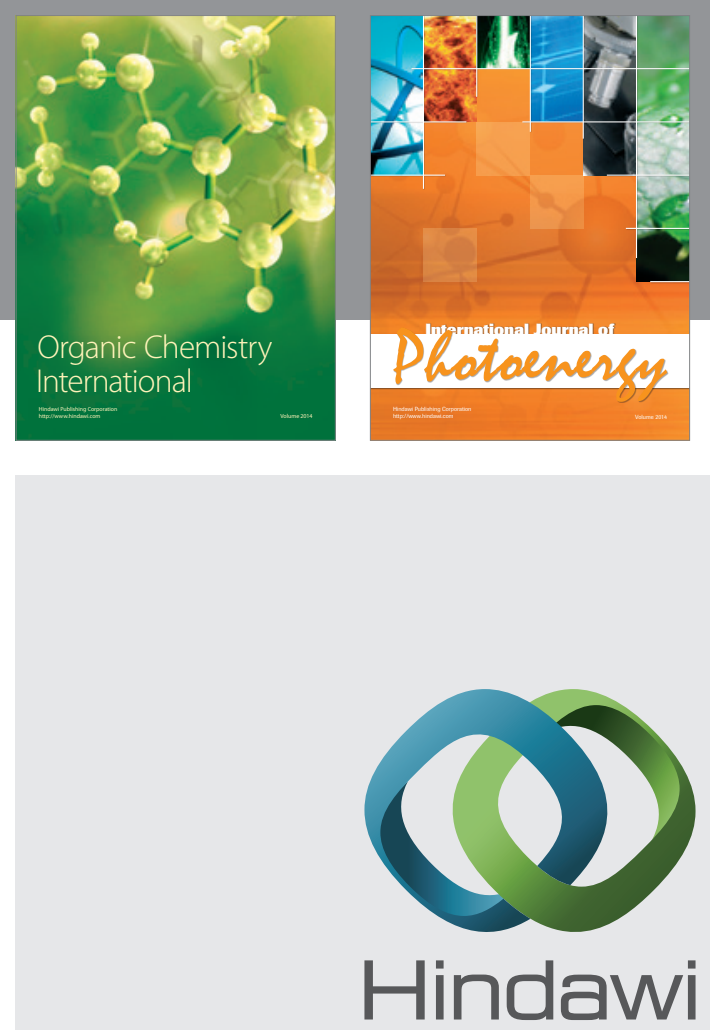

Submit your manuscripts at

http://www.hindawi.com
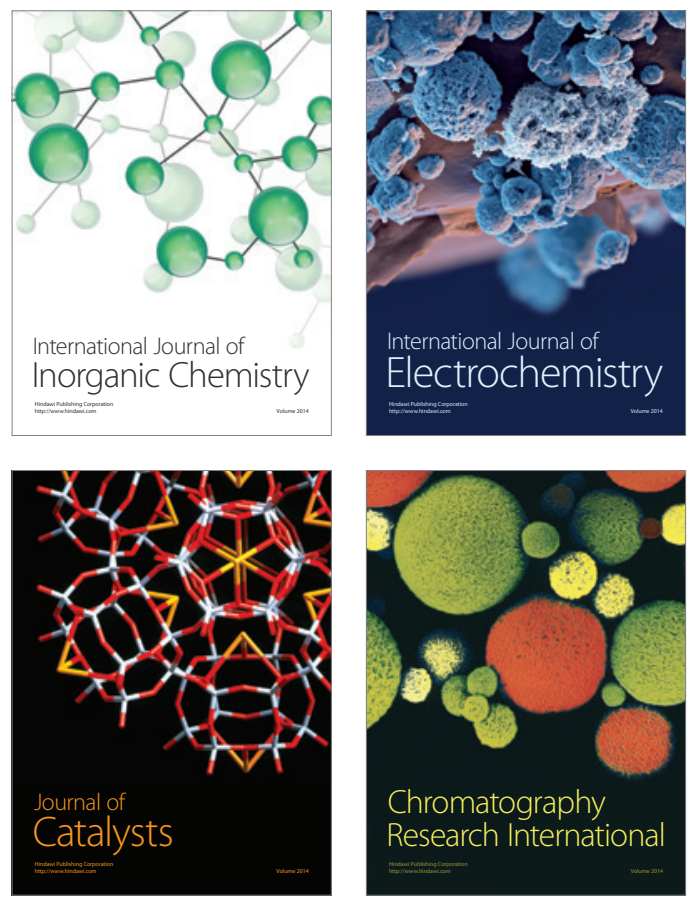
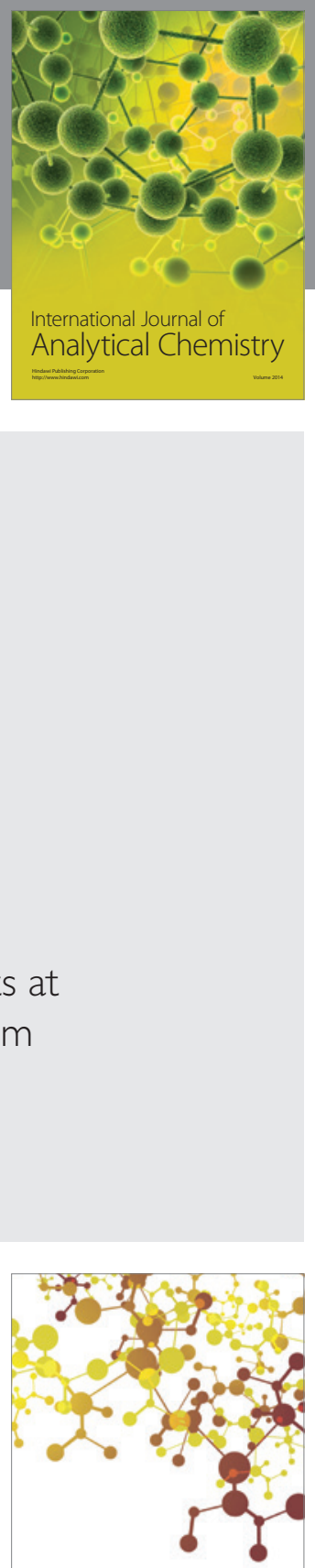

Journal of

Applied Chemistry
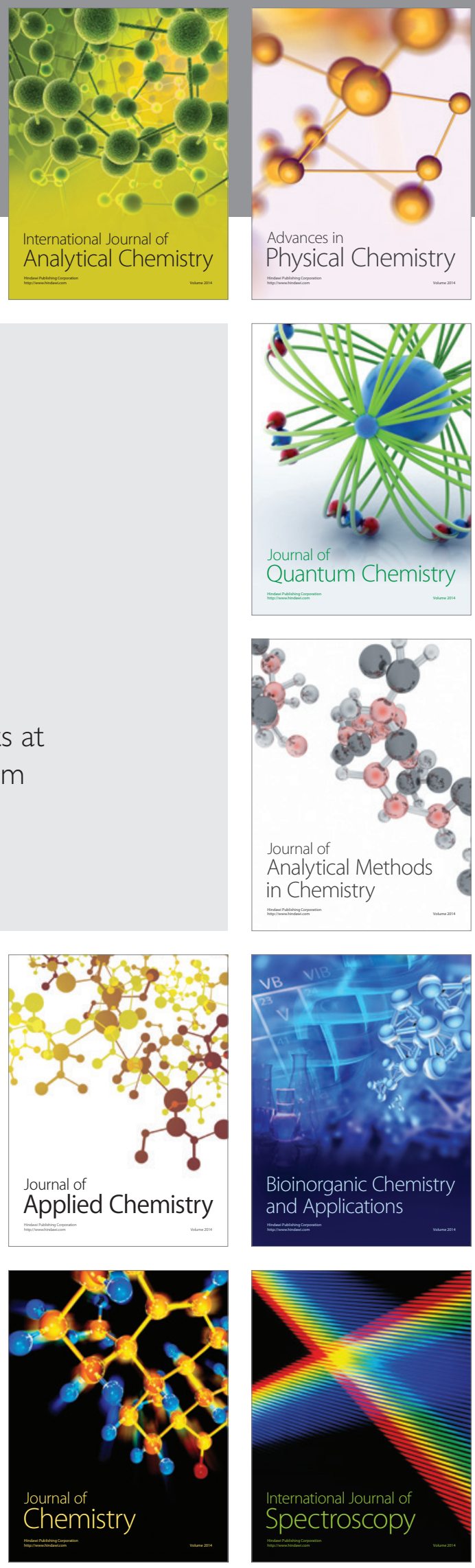